\title{
Changes in Jaw Dimensions and Bone Density in Patients with Osteoporosis
}

\author{
Srđan D. Poštić \\ Department of Prosthodontics, School of Dentistry, University of Belgrade, Belgrade, Serbia
}

\begin{abstract}
Summary
Introduction Osteopenia and osteoporosis reduce the density and mass of jaw bones.

Aim The aim of this study was to present the methods of radiographic analysis in patients with osteoporosis prior to restorative treatment.

Method 127 panoramic radiographs (Kodak, USA) and 39 retroalveolar radiographs (KD 58-R 30×40 mm, USA) were used for the analysis of density (DT II 05 densitometer, England) and dimensions of jaw bones with respect to segments corresponding to bone layers.

Results The results of this study indicated statistically significant differences in bone density $(p<0.05$ and $p<0.01)$ in patients with osteopenia. Bone density was significantly reduced $(p<0.01$ and $p<0.001)$ in osteoporotic patients, when compared to controls. Significant reductions of edentulous ridges in osteoporotic patients - women $\bar{X}=23.05$ $\mathrm{mm}(\mathrm{kV}=30.72 \%)$ and $\bar{X}=22.85 \mathrm{~mm}(\mathrm{kV}=28.81 \%)$, and men $\bar{X}=28.83(\mathrm{kV}=8.55 \%)$ as well as $\bar{X}=25.36(\mathrm{kV}=11.43 \%)$, were observed.

Conclusion Bone density of the upper and lower jaw is reduced in osteoporotic patients. At the very beginning of restorative prosthodontic therapy of osteoporotic patients, retroalveolar radiographs and panoramic radiographs should be obtained. Reference lines should be assigned, contours of the alveolar and edentulous ridges on radiographs should be analysed and bone density assessed.
\end{abstract}

Keywords: osteoporosis; edentulism; mandible; maxilla

\section{INTRODUCTION}

Osteopenia and osteoporosis induce the reduction of bone mass in human jaws [1-13]. Reduced blood flow to mandibular compact bone layers and systemic osteoporosis could result in significant reduction of residual ridges [14].

From the standpoint of treatment planning and restorative procedures in the rehabilitation of toothless and edentulous osteoporotic patients, atrophic residual alveolar ridges and bone reduction in osteoporotic layers after tooth extraction are of particular concern. In this respect, the most significant part of any therapeutic approach should be quality assessment of osteoporotic jaw bone condition.

In spite of the fact that numerous techniques and up-todate scanning devices contribute to improvements in diagnostic procedures and therapy, panoramic radiographs and retroalveolar dental radiographs remain the valuable and reliable method of assessing dimensions, mass and bone density in clinical dental practice and research.

The aim of this study was to present the methods of radiographic analysis in patients with osteoporosis prior to restorative treatment and rehabilitation of edentulous jaws.

\section{MATERIAL AND METHODS}

Material of this study consisted of 127 panoramic radiographs (Kodak, USA) and 39 retroalveolar dental radiographs (KD 58-R 30×40 mm, USA) of patients with osteopenic or osteoporotic decrement of bone density. Seventeen men, 59-90 years of age, and 46 women, $45-83$ years of age, were the subjects in this study. Panoramic radiographs, two radiographs for every patient, were obtained (Orthopantomograph 10, Siemens, Germany) in intervals of up to 5 months.

The methods of this study can be divided to the methods used in the analysis of panoramic radiographs and retroalveolar dental radiographs.

Regarding the analysis of panoramic radiographs, the analysis of reference lines and bone density within the segments of interest should be explained.

The analysis of reference lines was used for panoramic radiographs not only in patients with remaining teeth (Figure 1), but also in edentulous patients (Figure 2). Based on the assigned reference lines, the contours of residual ridge crest (contour of alveolar ridge of dentate patients as well as contour of the crest of edentulous ridge) were analysed. The height, i.e. level of crestal surface, was measured in relation to the reference lines and the data on the ridge height and reduction of residual ridges were provided [13, 14].

The analysis of pre-determined segments was done using two different approaches. The first approach was conducted to estimate the relationship of bone density and the reduction of osteoporotic residual ridge. Using a grid (each square was $2 \times 2 \mathrm{~mm}$ ), and assigning reference lines in the middle of mandibular contour on a panoramic radiograph (in the region of mental foramina and in the posterior region), the dimensions and borders of bone segments, vertically-perpendicular to the lower edge of panoramic radiograph, were determined. (Figures 3 and 4 ). 


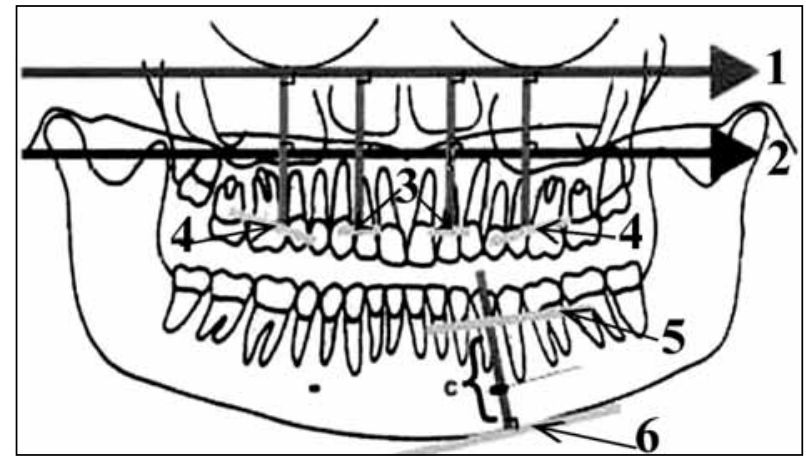

Figure 1. Schematic representation of panoramic radiograph analysis in osteoporotic patient with remaining teeth

Slika 1. Shematski prikaz analize OPG pacijenta obolelog od osteoporoze sa preostalim zubima u vilicama

1 - reference line at maxillary base;

2 - reference line in the level of coronoid processes tip projection under negative remodelling of osteoporotic condyles;

3 - reference line in the anterior segment of the upper ridge;

4 - reference line at the posterior surface of the upper ridge;

5 - reference line of mandibular alveolar ridge contour:

6 - reference line at mandibular base; Vertical lines quantifying vertical dimension - height of the alveolar ridge with respect to the base of jaw bone.

1 - referentna linija pri bazi gornje vilice;

2 - referentna linija ispod kondila mandibule izmenjenih osteoporozom, koja dodiruje vrhove koronoidnih nastavaka mandibule:

3 - referentna linija u anteriornom sektoru na površini konture alveolarnog grebena oko zuba u gronjoj vilici;

4 - referentna linija na površini alveolarnog grebena u transkaninom sektoru u gornjoj vilici;

5 - referentna linija na površini alveolarnog grebena oko preostalih zuba u donjoj vilici;

6 - referentna linija uz bazu donje vilice; Uzdužne linije označavaju vertikalnu dimenziju, visinu grebena u odnosu na bazu kosti.

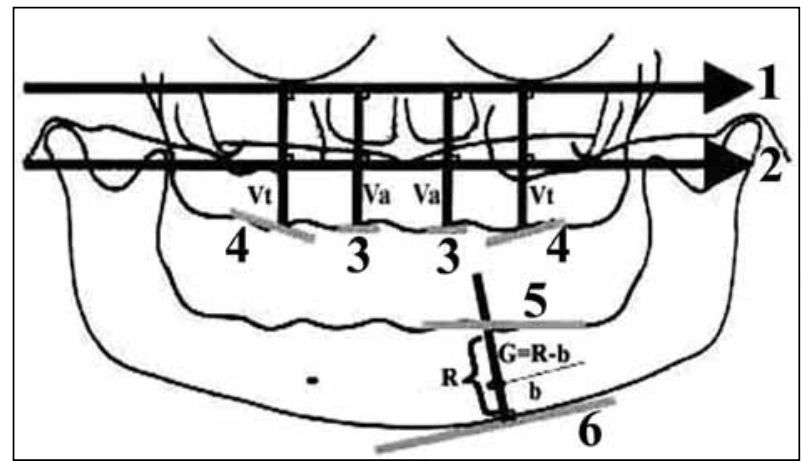

Figure 2. Schematic representation of panoramic radiograph of osteoporotic edentulous patient

Slika 2. Shematski prikaz analize OPG bezubog pacijenta sa osteoporozom

1 - reference line at maxillary base;

2 - reference line in the level of coronoid processes tip projection under negative remodelling of osteoporotic condyles;

3 - reference line and contour of residual ridge in the anterior region;

4 - reference line at the lateral surface contour of edentulous ridge of

maxillary bone;

5 - reference line on the crest of edentulous ridge of the lower jaw;

6 - reference line at mandibular base; Vertical lines assigning vertical dimension - height of edentulous ridge in relation to the basal layers of jaw bones.

1 - referentna linija pri bazi gornje vilice;

2 - referentna linija ispod kondila mandibule izmenjenih osteoporozom,

koja dodiruje vrhove koronoidnih nastavaka mandibule;

3 - referentna linija u anteriornom sektoru na površini konture bezubog grebena;

4 - referentna linija na površini bezubog grebena gornje vilice;

5 - referentna linija na bezubom grebenu donje vilice;

6 - referentna linija uz bazu donje vilice; Uzdužne linije označavaju vertikalnu dimenziju, visinu bezubog grebena u odnosu na bazu kosti.
The second approach was used to determine borders and positions of segments with inclinations towards distal parts, with reference to the lower edge of panoramic radiograph (Figure 5) [14].

The analysis of retroalveolar radiographs was based on the bordering and assessing quadrants within the grid. The quadrants within the border, assigned for the area of interest, were determined with respect to tooth roots in the jaw (Figures 6 and 7).

Bone density was assessed using a digital densitometry device DT II 05 (England) [3, 13, 15].

\section{RESULTS}

The obtained data for pre-determined segments of the jaws suggested significant reduction in bone density when compared to the controls (Table 1) $[6,13,15]$. Statistically significant differences in bone density $(\mathrm{p}<0.05$ and $\mathrm{p}<0.01)$ were observed in osteopenic patients (Table 2). Statistically significant differences in density $(\mathrm{p}<0.01$ and $\mathrm{p}<0.001)$ and the significant reduction of total density was calculated in osteoporotic patients (Table 3).

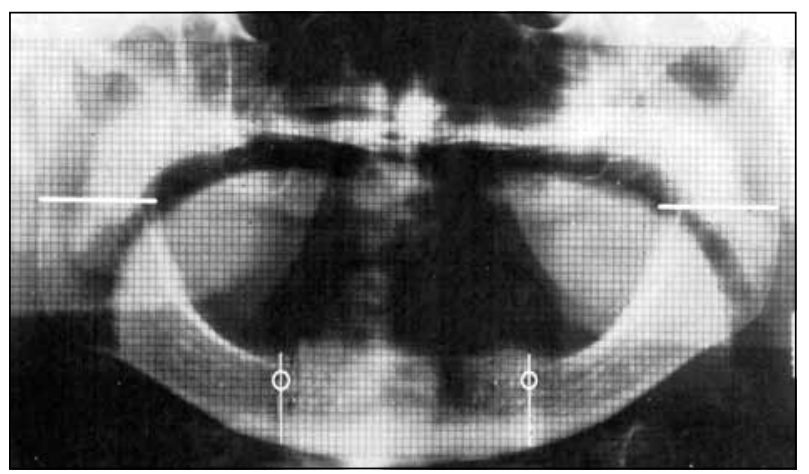

Figure 3. Grid positioned on a panoramic radiograph of an osteoporotic patient and borders of areas of interest: horizontal line in the middle of ramus and vertical line in the area of mental foramina.

Slika 3. Mreža na ortopantomogramu bezubog pacijenta s osteoporozom i označene granice površina kosti koje su značajne u istraživanju: horizontalna linija na sredini ramusa mandibule i vertikalna linija u regionu foramena mentale, desno i levo.

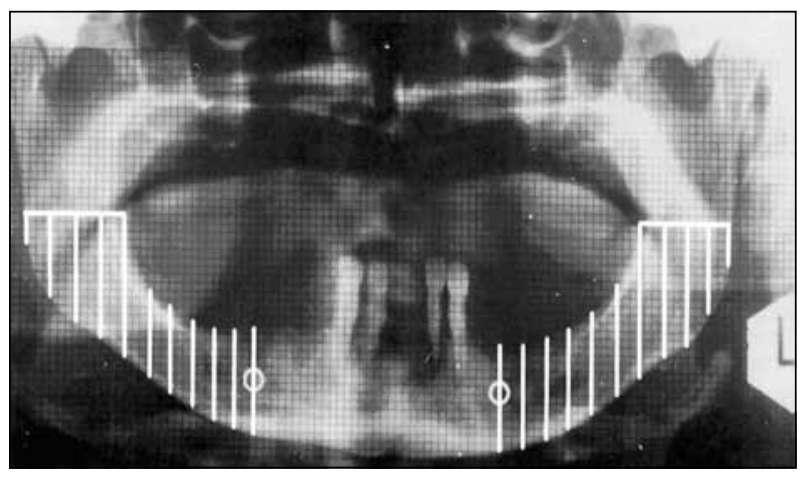

Figure 4. Vertical position of determined segments of bone to lower edge of a dental panoramic radiograph. White lines determine borders of areas of interest -10 decils to the right and 10 decils to the left side of panoramic radiographs.

Slika 4. Vertikalno u odnosu na donju ivicu filma orijentisani segmenti kosti koji su značajni u istraživanju. Svetlim linijama su označene granice 10 segmenata kosti (decila) na desnoj strani i 10 segmenata kosti (decila) na levoj strani. 


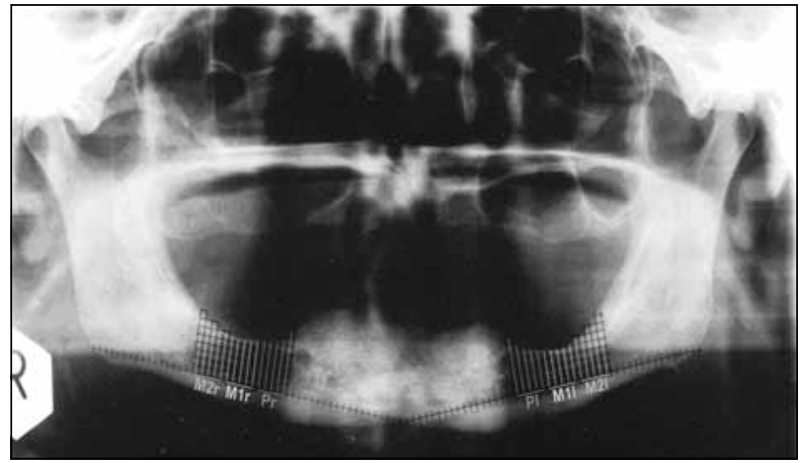

Figure 5. Distal inclination of decil borders-areas of interest in the study Slika 5. Koso (u distalnom smeru) orijentisane granice segmenata kosti (decila) koji su značajni u istraživanju

$\mathrm{Pr}$ - decils at the level of missing premolar root to the right side; $\mathrm{PI}$ - decils at the level of missing premolar root to the left side; $\mathrm{M} 1 \mathrm{r}$ - decils at the level of missing roots of the first lower molar to the right side; $\mathrm{M} 1 \mathrm{l}$ - decils at the level of missing roots of the first lower molar to the left side; $\mathrm{M} 2 \mathrm{r}$ - decils at the level of missing roots of the second lower molar to the right side; M2l decils at the level of missing roots of the second lower molar to the left side $\mathrm{Pr}$ - decili koji odgovaraju površini kosti gde nedostaje koren premolara na desnoj strani; PI - decili koji odgovaraju površini kosti gde nedostaje koren premolara na levoj strani; M1r - decili koji odgovaraju površini kosti gde nedostaju korenovi donjeg prvog molara na desnoj strani; M11 - decili koji odgovaraju površini kosti gde nedostaju korenovi donjeg prvog molara na levoj strani; $\mathrm{M} 2 \mathrm{r}$ - decili koji odgovaraju površini kosti gde nedostaju korenovi donjeg drugog molara na desnoj strani; M2l - decili koji odgovaraju površini kosti gde nedostaju korenovi donjeg drugog molara na levoj strani

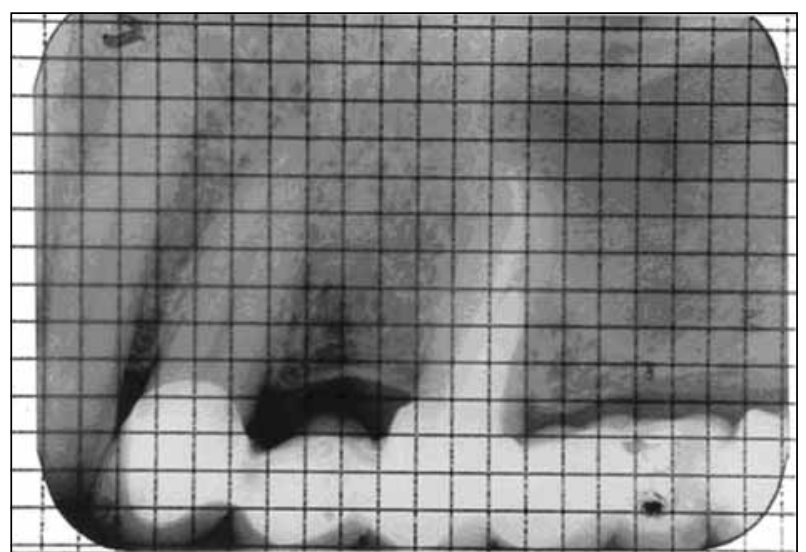

Figure 6. Retroalveoar dental radiograph of an osteoporotic patient and grid with quadrants

Slika 6. Retroalveolarni radiogram pacijenta s osteoporozom i mreža kvadrata

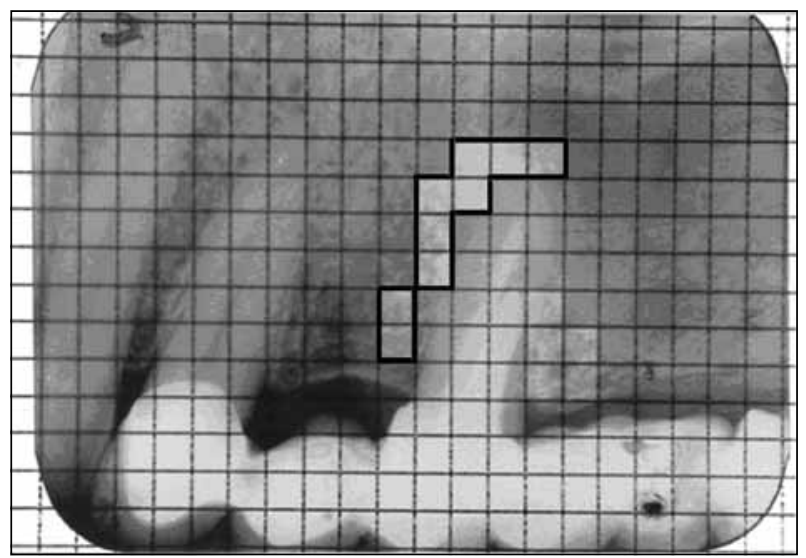

Figure 7. Determined borders of areas of interest for the analysis of alveolar bone density

Slika 7. Označene granice regiona na retroalveolarnom radiogramu koje su značajne u istraživanju

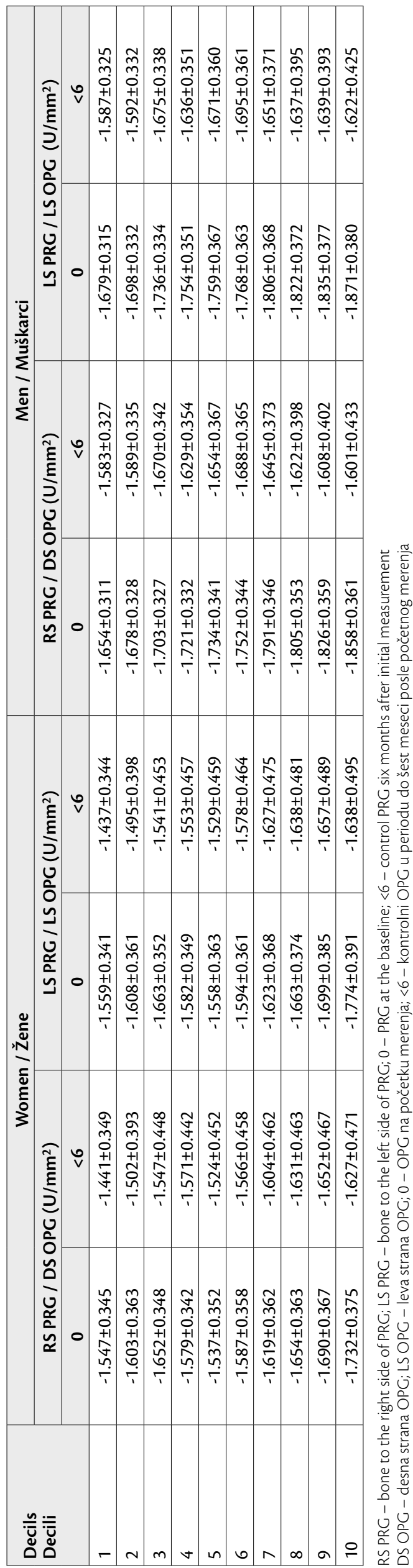


Table 2. Statistical significance of alveolar bone and residual ridge density in osteopenic patients

Tabela 2. Statistička značajnost razlika gustine alveolarne kosti i grebena pacijenata obolelih od osteopenije

\begin{tabular}{|c|c|c|}
\hline $\begin{array}{c}\text { Decils } \\
\text { Decili }\end{array}$ & $\begin{array}{c}\text { Premolar regions } \\
\text { Regije premolara }\end{array}$ & $\begin{array}{c}\text { Molar regions } \\
\text { Regije molara }\end{array}$ \\
\hline $\begin{array}{c}\text { RS PRG } \\
\text { DS OPG }\end{array}$ & $\mathrm{p}<0.01$ & $\mathrm{p}<0.05$ \\
\hline $\begin{array}{c}\text { LS PRG } \\
\text { LS OPG }\end{array}$ & $\mathrm{p}<0.01$ & $\mathrm{p}<0.05$ \\
\hline
\end{tabular}

Table 3. Statistical significance of alveolar bone and residual ridge density in osteoporotic patients

Tabela 3. Statistička značajnost razlika gustine alveolarne kosti i grebena pacijenata obolelih od osteoporoze

\begin{tabular}{|c|c|c|c|}
\hline $\begin{array}{c}\text { Decils } \\
\text { Decili }\end{array}$ & $\begin{array}{c}\text { Region } \\
\text { Regija }\end{array}$ & $\begin{array}{c}\text { RS PRG } \\
\text { DS OPG }\end{array}$ & $\begin{array}{c}\text { LS PRG } \\
\text { LS OPG }\end{array}$ \\
\hline 1 & $\begin{array}{c}\text { Premolar } \\
\text { Premolar }\end{array}$ & $\mathrm{p}<0.001$ & $\mathrm{p}<0.001$ \\
\hline 2 & $\begin{array}{c}\text { Premolar } \\
\text { Premolar }\end{array}$ & $\mathrm{p}<0.001$ & $\mathrm{p}<0.001$ \\
\hline 3 & $\begin{array}{l}\text { Molar } \\
\text { Molar }\end{array}$ & $\mathrm{p}<0.001$ & $\mathrm{p}<0.001$ \\
\hline 4 & $\begin{array}{l}\text { Molar } \\
\text { Molar }\end{array}$ & $\mathrm{p}<0.001$ & $\mathrm{p}<0.001$ \\
\hline 5 & $\begin{array}{l}\text { Molar } \\
\text { Molar }\end{array}$ & $\mathrm{p}<0.001$ & $\mathrm{p}<0.001$ \\
\hline 7 & $\begin{array}{l}\text { Molar } \\
\text { Molar }\end{array}$ & $\mathrm{p}<0.001$ & $\mathrm{p}<0.001$ \\
\hline 8 & $\begin{array}{l}\text { Molar } \\
\text { Molar }\end{array}$ & $\mathrm{p}<0.01$ & $\mathrm{p}<0.01$ \\
\hline 9 & $\begin{array}{l}\text { Ramus } \\
\text { Ramus }\end{array}$ & $\mathrm{p}<0.01$ & $\mathrm{p}<0.01$ \\
\hline 10 & $\begin{array}{c}\text { Cortical bone } \\
\text { Korteks kosti }\end{array}$ & $\mathrm{p}<0.01$ & $\mathrm{p}<0.01$ \\
\hline
\end{tabular}

Very low bone density, that was statistically significant, was observed not only in the analysis of bone segments oriented perpendicular to the lower edge of panoramic radiographs, but also in the analysis of distally inclined segments of the bone.

Low bone density was observed on retroalveolar radiographs of osteoporotic patients in areas close to tooth roots, with respect to compact basal bone layers.

Significant reduction in bone mass of residual ridges was observed in osteoporotic patients. The most intensive reduction was in the area of missing premolars and lower first molar for both women, $\overline{\mathrm{X}}=23.05$; (coefficient of variation $\mathrm{kV}=30.72 \%)$ and $\overline{\mathrm{X}}=22.85(\mathrm{kV}=28.81 \%)$, and men, $\bar{X}=28.83(\mathrm{kV}=8.55 \%)$ and $\overline{\mathrm{X}}=25.36(\mathrm{kV}=11.43 \%)$.

\section{DISCUSSION}

Panoramic radiographs are widely used as supplemental diagnostic recordings for numerous clinical situations, not only at the very beginning of the treatment of partially but also completely edentulous patients.

In spite of recent modifications and digitalization of OPT devices, scanning methods and other methods of bone assessment, conventional panoramic radiographs are successfully used for the analysis of bone density and dimension of jaw bones [1-15].

Determination of reference lines in the analysis of panoramic radiographs is a very important part of the analysis. The position of reference lines on panoramic radiographs should refer to maxillary base and basal layers of mandibular corpus. The reference line related to the maxillary base should be used in the analysis of edentulous ridge contour. This contour should be particularly determined with respect to anterior segments of the upper edentulous ridge - intercanine area of the crestal bone and transcanine - lateral surface of the residual ridge. For the lower jaw, the exact height of the crest of edentulous ridge and residual ridge should be calculated based on the levels of mental foramina and used as an important numerical value at the beginning of restorative, i.e. prosthodontic treatment of partially edentulous jaws, as well as of edentulous jaws.

The analysis of bone segments perpendicular to the lower edge of panoramic radiographs, should be considered as a reference for the comparison and correlation with reduction of residual ridge, but should be used for treatment planning and medication of the jaws. The analysis of bone density related to the inclination of determined segments should be used in treatment planning with single implants or specific disc implants. This is of particular importance in the assessment of the inclination of definitive position of implants in the future, as well as in the analysis of the resistance of implants to vertical loading in osteoporotic bone support [13].

Retroalveolar dental radiographs should be used when patients with osteoporosis have a few reamining teeth. Based on this analysis it is possible to assess the intensity of degradation of jaw bone as well as the reduction of alveolar bone density. However, retroalveolar radiographs are not helpful for the analysis of residual ridges of edentulous osteoporotic patients.

The assessment of alveolar bone density should be very important in treatment planning, designing dentures and "pre-prosthetic preparation of osseous segment", which should be realized by appropriate medication for the initiation of positive alveolar bone remodeling.

The grid and quadrants $(2 \times 2 \mathrm{~mm}$ each) were used in this study because of the identical values of the radius of focused light beam of the digital densitometry DTII apparatus $[13,15]$. Nevertheless, it should be possible to determine the extended area on panoramic radiographs, as well as on retroalveolar dental radiographs, and apply specific procedures to quantify alveolar bone density of particular areas [13].

Regarding the rehabilitation of edentulous maxilla, significant reduction of residual ridge density should not be a discouraging circumstance because of the possibility to extend the denture base to the palatal surface. Despite this fact, quantification of bone density of edentulous maxillary ridge is strongly recommended.

Regarding the complexity and difficulties in the analysis of maxillary bone density on panoramic radiographs, two noteworthy problems are present. The first one is related to the superposition of sinus and nasal cavities. 
Moreover, residual maxillary ridge is expected to be positioned very close to the maxillary base. Because of that, reference lines towards the maxillary base may be of great importance for orientation during the analysis of maxillary surfaces on panoramic radiographs.

As of the analysis of crestal position, in respect to the reference lines of the mandible, the analysis is less defficult because of the considerable mass of the lower jaw, particularly the basal layers, and because of the absence of super positioning to adjacent bones and cavities. However, considering practical aspect of prosthodontic rehabilitation of edentulous lower jaw with the complete denture, the problem of residual mandibular ridge reduction may be more complex (the problem of denture stability on significantly reduced residual ridge).

For a great number of osteoporotic patients, negative remodellations of condyles and temporo-mandibular joints were observed on panoramic radiographs, indicating dysfunctions of temporo-mandibular joints and orofacial systems of these patients.

It should not be obligatory to obtain two panoramic radiographs, at the baseline and after 6 months, for each patient with osteoporosis. The first panoramic radiograph should be obtained prior to the restorative therapy and this may be accompanied with a systemic record of total skeletal-bone density (DXA; DPA). The total of two panoramic radiographs should be obtained at the baseline-prior to the treatment and after several weeks or 6 months at the end of therapy - after positioning of dentures. For this experiment, two panoramic radiographs were provided - one before restorative prosthodontic therapy, and the second one as a consequence of suspected osteoporosis of jaws prior to medication of systemic osteoporosis, or during the break inmedication, for a number of osteoporotic patients.

Regarding alveolar bone density of the jaws, particularly the lower jaw, it is recommended to quantify the variations in density during osteopenia. Regarding the osteoporotic changes in jaw bone density and composition, panoramic radiographs should be an additional radiographic diagnostic tool for initial osteoporosis (transition phase of osteopenia to osteoporosis), when layers of bone are not yet significantly degraded.

The inaccuracy of panoramic recording of the lower jaws may be in head and chin positioning of the plastic frame - chin holder, which may result in moderate superposition of plastic and anterior segments of mandibular corpus. Hence, it is recommended to obtain separate retroalveoar dental radiographs of alveolar bone in the lower incisor areas, considering these regions to be predisposed for reduction because of abundant spongy bone layers.

\section{CONCLUSION}

Alveolar bone density of maxilla and mandible is continually reduced as a consequence of osteoporosis. Prior to restorative therapy of the oral-facial system in patients with osteoporosis, reference-lines, dimension and contours of residual ridges should be determined and alveolar bone density assessed on panoramic and retroalveolar dental radiographs.

\section{REFERENCES}

1. Erdogan $O$, Shafer DM, Taxel P, Freilich M. A review of the association between osteoporosis and alveolar ridge augmentation. Oral Surg Oral Med Oral Pathol Oral Radiol Endod. 2007; 104:738e1-13.

2. Goldberg AF, Gergans GA, Mattson DE, Rudman D. Radiographic alveolar process - mandibular height ratio as a predictor of osteoporosis. Gerodontics. 1988; 4:229-31.

3. Horner K, Devlin H. Clinical bone densitometric study of mandibular atrophy using dental panoramic tomography. J Dent. 1992; 20:33-7.

4. Jefcoat $\mathrm{M}$, Chesnut $\mathrm{CH}$. Systemic osteoporosis and oral bone loss. JADA. 1993; 124:49-56.

5. Poštić SD, Marković $\vee$, Veselinović D, Mirjanić M, Zec S. Physicalchemic characterisation of osteoporotic bone. J Dent Res. 2002; 81(Special Issue B):B284.

6. Poštić SD, Rakočević Z, Krstić M, Pilipović N. A densitometric appraisal of mandibular segments in osteoporotic subjects. Progress in Osteoarthrology. 1997; 9:81-2.

7. Poštić SD, Krstić MS, Rakočević Z, Jevremović M, Goldner B, Pilipović $\mathrm{NZ}$, et al. Promene u donjoj vilici kod pacijentkinja sa osteoporozom, pristup i mogućnosti terapije. Acta Medica Semendrica. 1998; VI:161-5.

8. Poštić SD. Uslovljenost smanjivanja kostnih slojeva donjih vilica sistemnim promenama skeleta usled osteoporoze. Glasnik Antropološkog društva Jugoslavije. 2006; 41:163-76.

9. Poštić SD. Promene u mandibuli usled osteoporoze. Stomatološki glasnik Srbije. 2007; 54:16-27.

10. Available at: www.fda.gov/ohrms/dockets/ac/98/transpt/3463t2.rtf

11. Von Wowern N. Bone mass of mandibles. Dan Med Bull. 1986; 33:23-44.

12. Von Wowern N, Kollerup G. Symptomatic osteoporosis: A risk factor for residual ridge reduction of the jaws. J Prosthet Dent. 1992; 67:656-60.

13. Poštić SD. Analiza osteoporotičnih promena u donjoj vilici i njihov klinički značaj [doktorska disertacija]. Beograd: Univerzitet u Beogradu; 1998.

14. Poštić SD. Osteopenične i osteoporotične promene u segmentima mandibula. Beograd: Zadužbina Andrejević; 2000. p.19-82.

15. Rakočević Z, Poštić S. Procena vrednosti denzitometrijskih merenja u analizi gustine kosti. XXIV kongres antropološkog društva Jugoslavije sa međunarodnim učešćem; 1995.

\author{
Address for correspondence \\ Srđan D. Poštić \\ Klinika za stomatološku protetiku \\ Stomatološki fakultet \\ Rankeova 4, 11000 Beograd \\ Srbija \\ Email: srdjan.postic@stomf.bg.ac.rs
}




\title{
Promene dimenzija vilica i gustine kosti osoba obolelih od osteoporoze
}

\author{
Srđan D. Poštić \\ Klinika za stomatološku protetiku, Stomatološki fakultet, Univerzitet u Beogradu, Beograd, Srbija
}

\begin{abstract}
KRATAK SADRŽAJ
Uvod Osteopenija i osteoporoza uzrokuju smanjenje mase i gustine vilica.

Cilj rada Cilj rada je bio da se prikažu postupci u analizi radiograma vilica osoba obolelih od osteoporoze pre početka restaurativnog zbrinjavanja krezubosti i bezubosti.

Materijal i metode rada Kao materijal za analizu gustine (DTII05 densitometer, England) i dimenzija kosti po određenim segmentima prema površinama slojeva kostiju vilica korišćeno je 127 ortopantomograma (Kodak, USA) i 39 retroalveolarnih radiograma (KD 58-R 30×40 mm, USA).

Rezultati Statistički manje značajne promene i smanjenja gustine ( $p<0,05$ i $p<0,01)$ utvrđena su kod ispitanika obolelih od osteopenije. Statistički vrlo značajne razlike $(p<0,01$ i $p<0,001)$ i veoma smanjene vrednosti gustine kostiju vilica uočene su kod ispitanika obolelih od osteoporoze. Izmerena su i značajna smanjenja bezubih grebenova osteoporoznih vilica, koja su kod žena bila $23,05 \mathrm{~mm}$ (koeficijent varijacije 30,72\%) i 22,85 mm (koeficijent varijacije 28,81\%), a kod muškaraca 28,83 mm (koeficijent varijacije $8,55 \%$ ) i $25,36 \mathrm{~mm}$ (koeficijent varijacije 11,43\%).

Zaključak Gustina kosti u gornjoj i donjoj vilici je uvek smanjena usled osteoporoze. Pre početka restaurativnog lečenja osoba obolelih od osteoporoze neophodno je napraviti ortopantomogram i retroalveolarni radiogram, označiti referentne linije, sagledati konture koštanih grebenova i proceniti gustinu kosti.
\end{abstract}

Ključne reči: osteoporoza; bezubost; mandibula; maksila

\section{UVOD}

Osteopenija i osteoporoza uzrokuju smanjenje mase i gustine kosti donje i gornje vilice čoveka [1-13]. Smanjen dotok krvi i otežana cirkulacija udruženi sa sistemskom osteoporozom mogu dovesti do izrazitog gubitka koštane supstance rezidualnog (bezubog) grebena, posebno u mandibuli [14].

S aspekta planiranja i pristupanja restaurativnoj i stomatoprotetičkoj rehabilitaciji krezubih ili bezubih pacijenata kod kojih je gustina kosti smanjena usled osteoporoze, posebne teškoće stvaraju redukovani i atrofični alveolarni grebenovi, odnosno bezubi grebenovi koji preostaju u osteoporoznim vilicama posle vađenja zuba. U tom smislu, najznačajniji postupak na početku analize i planiranja lečenja ovih bolesnika jeste pravilna procena stanja kostiju vilica.

Bez obzira na veliki broj savremenih metoda koje se primenjuju u ispitivanju struktura i slojeva kostiju vilica, ortopantomogrami (OPG) i retroalveolarni snimci (RAG) su pokazali najveću praktičnu i upotrebnu vrednost u proceni stanja (dimenzija, gustine i mase) kosti gornje i donje vilice, ne samo s aspekta naučnostručnih i istraživačkih radova, već i u kliničkom radu i svakodnevnoj ambulantnoj praksi.

Cilj ovoga rada je bio da se prikažu postupci u analizi radiograma vilica osoba obolelih od osteoporoze pre početka restaurativnog zbrinjavanja krezubosti i bezubosti.

\section{MATERIJAL I METODE RADA}

Kao materijal u istraživanju korišćeno je 127 OPG (Kodak, USA) i 39 RAG (KD 58-R 30x40 mm, USA) pacijenata sa smanjenom gustinom kosti usled osteopenije ili osteoporoze. Muškaraca je bilo 17, starosti između 59 i 90 godina, a žena 46, starih od 45 godina do 83 godine. Za svakog ispitanika načinjena su po dva
OPG (Orthopantomograph 10, Siemens, Germany) u intervalima do pet meseci.

Opis metoda koje su primenjene $u$ istraživanju može biti uslovno raščlanjen na opis metoda koje su primenjene pri analizama OPG, odnosno RAG. Od metoda koje su korišćene $\mathrm{u}$ analizi OPG treba izdvojiti analizu na osnovu referentnih linija i analizu gustine kosti po segmentima.

Metoda analize na osnovu referentnih linija je korišćena $u$ analizi OPG pacijenata koji su imali preostale zube u vilicama (Slika 1) i pri analizi OPG bezubih pacijenata (Slika 2). Na osnovu označenih referentnih linija posmatrane su konture grebenske površine (konture alveolarnog grebena pacijenata s preostalim zubima ili konture rezidualnih bezubih grebenova bezubih pacijenata). U odnosu na referentne linije izmereni su visina $i$ nivo površine grebena, te dobijeni podaci o numeričkim vrednostima visine grebena i smanjenju njegove površine [13, 14].

Metoda analize po izdvojenim segmentima je obavljena na dva različita načina. Prvi način je primenjen kako bi se utvrdila povezanost gustine kosti u označenim segmentima sa smanjenjem grebena usled osteoporoze. Na osnovu milimetarske defragmentacije i kvadrata jednakih dimenzija $(2 \times 2 \mathrm{~mm}) \mathrm{u}$ mreži, te označavanja referentnih linija na sredini prikazane mandibule na OPG, odnosno u regionu foramena mentale i distalno, utvrđene su dimenzije i granice segmenata kosti vertikalno - pod pravim uglom u odnosu na donju ivicu OPG (Slike 3 i 4).

Drugim načinom su određeni granice i položaji segmenata pod uglom - sa iskošenjem prema distalno u odnosu na donju ivicu OPG (Slika 5) [14].

Metode koje su korišćene u analizi RAG takođe su se zasnivale na obeležavanju kvadrata u okviru mreže. Raspored položaja kvadrata je utvrđen prema regionima kosti oko korenova preostalih zuba u vilicama (Slike 6 i 7).

Za procenu gustine kosti primenjen je digitalni elektronski denzitometar (DTII05, England) $[3,13,15]$. 


\section{REZULTATI}

$\mathrm{Na}$ osnovu merenja promena gustine kosti u granicama označenih segmenata, regiona vilica, utvrđena su značajna smanjenja gustine kosti u poređenju s ranije ustanovljenom referentnom grupom ispitanika (Tabela 1) $[6,13,14]$. Statistički manje značajne promene i smanjenja gustine $(\mathrm{p}<0,05 \mathrm{i} p<0,01) \mathrm{su}$ utvrđena kod ispitanika obolelih od osteopenije (Tabela 2). Statistički vrlo značajne razlike ( $\mathrm{p}<0,01$ i $\mathrm{p}<0,001)$ i veoma smanjene vrednosti gustine kosti su zabeležene kod ispitanika obolelih od osteoporoze (Tabela 3).

Statistički značajno manja gustina kosti je utvrđena i pri analizi segmenata orijentisanih vertikalno - pod pravim uglom u odnosu na donju ivicu filma, i pri analizi segmenata orijentisanih koso u odnosu na ivicu OPG. Manja gustina kosti ustanovljena je na RAG oko korenova zuba pacijenata s osteoporozom u odnosu na kompaktne i masivnije slojeve pri bazi kosti.

Kod ispitanika obolelih od osteoporoze je posebno uočeno značajno smanjenje mase bezubog grebena, a najviše u regionima kosti gde su nedostajali korenovi premolara i korenovi donjih molara. Ova smanjenja su kod žena iznosila 23,05 mm (koeficijent varijacije $30,72 \%$ ) i 22,85 mm (koeficijent varijacije $28,81 \%$ ), a kod muškaraca $28,83 \mathrm{~mm}$ (koeficijent varijacije $8,55 \%$ ) i $25,36 \mathrm{~mm}$ (koeficijent varijacije $11,43 \%$ ).

\section{DISKUSIJA}

OPG je izuzetno važno pomoćno dijagnostičko sredstvo i dokument koji je dosada opravdano korišćen u brojnim situacijama u kliničkoj praksi na početku, odnosno pre protetičkog (restaurativnog) zbrinjavanja krezubih ili bezubih pacijenata. Bez obzira na digitalizaciju ortopantomografskih aparata, skeniranje i savremene metode, OPG načinjeni klasičnim postupkom su uspešno korišćeni u analizi gustine kosti i sagledavanju dimenzija vilica [1-15].

Veoma je značajno određivanje položaja i obeležavanje referentnih linija koje će biti korišćene pri analizi OPG. Na OPG treba utvrditi položaj referentne linije uz bazu gornje vilice, a na donjoj vilici treba odrediti referentnu liniju prema bazi donje vilice. U odnosu na referentnu liniju gornje vilice treba označiti i posmatrati konturu bezubog grebena gornje vilice, posebno po anteriornim segmentima - površine koje pripadaju interkaninom sektoru, a posebno posmatrati pravac i položaj konture prema transkaninom sektoru. U donjoj vilici na osnovu foramena mentale može se izračunati visina grebenskog sloja, što je posebno značajno kasnije, u terapiji mobilnim nadoknadama (totalnim ili parcijalnim protezama).

Analizu segmenata kosti orijentisanih upravno na donju ivicu filma treba primeniti pri poređenju i utvrđivanju korelacije sa smanjenjem grebena, kao i zbog kasnije primene medikamentne terapije. Analizu gustina u kosim segmentima treba koristiti pri planiranju postavljanja pojedinačnih implantata ili posebnih implantata tanjirastog oblika u bazi, sa ciljem procene budućeg položaja implantata u kosti pod iskošenjem u odnosu na delovanje vertikalnih sila [13].

RAG treba dati prednost kada pacijent oboleo od osteoporoze ima nekoliko preostalih zuba. Na osnovu RAG je moguće uspešno proceniti stepen razgradnje kosti i smanjenje gustine kosti.
$\mathrm{U}$ analizi bezubih regiona kod bezubih pacijenata RAG, međutim, ne može biti od velike koristi, već je bolje načiniti OPG.

Procena gustine kosti je veoma značajna zbog planiranja lečenja i tzv. preprotetičke pripreme koštanog segmenta, koju treba ostvariti primenom odgovarajućih medikamenata za inicijaciju pozitivnog remodelovanja kosti i lokalno povećavanje gustine kosti.

U ovom istraživanju je korišćena mrežica sa kvadratima dimenzija $2 \times 2 \mathrm{~mm}$ zato što aparat pomoću kojeg su merene oscilacije i razlike u gustinama slojeva kosti ima fokus zračnog snopa u okviru radijusa od $2 \mathrm{~mm}[13,15]$. Isto tako je moguće ne samo na RAG, nego i po OPG, označiti površinu šireg ili drugačijeg oblika, a posebnim postupkom merenja pomoću drugačijeg aparata izvršiti procenu gustine kosti prema površini od značaja [13].

Uprkos činjenici da, posebno s aspekta rehabilitovanja i terapije bezubih gornjih vilica, značajno smanjenje gustine kosti bezubog grebena bezube gornje vilice ne mora biti izuzetno otežavajuća okolnost, zbog mogućnosti ekstenzije baze proteze na površine tvrdog nepca, potrebno je izmeriti gustinu kosti gornje vilice.

U pogledu složenosti i teškoća $u$ analizi gustine kosti na OPG, nameću se dva uočljiva problema. Prvi problem je vezan za analizu gustine kosti gornje vilice na OPG, gde se superponiraju segmenti nosnih šupljina prema kosti i šupljine maksilarnih sinusa. Pored toga, bezubi greben je blizu baze kosti gornje vilice. $U$ tom smislu, referentna linija prema bazi gornje vilice može biti od izuzetne pomoći u orijentaciji za vreme analize površina grebena gornje vilice prikazanih na OPG. Kada je reč $\mathrm{o}$ analizi grebenske površine prema referentnim linijama uz bazu mandibule, postupak je jednostavniji zato što je kost donje vilice masivna, posebno prema bazi, te nema superponiranja s otvorima i šupljinama okolnih kosti. S praktičnog aspekta terapije i protetičkog zbrinjavanja, problem smanjenja donjeg bezubog grebena je mnogo veći i teže ga je rešiti zbog nestabilnosti donje totalne proteze na izrazito redukovanoj površini.

$\mathrm{Na}$ OPG su u značajnom broju slučajeva prikazane i izmene kontura zglobne glave mandibule i temporomandibularnog zgloba (TMZ), što bi verovatno moglo ukazati na to da osteoporoza negativno remodeluje i kondile, čime može uticati i na pojavu disfunkcija TMZ.

Kod osoba s osteoporozom nije neophodno načiniti dva OPG u intervalima do šest meseci. Jedan OPG pre početka restaurativne terapije može biti sasvim dovoljan, ali uz odgovarajući sistemski nalaz o ukupnoj kostnoj gustini skeleta (DXA; DPA). Dva OPG u različitim vremenskim intervalima mogu biti načinjena pre početka lečenja (prvi) i za vreme, odnosno po završetku terapije (drugi po redu snimak vilica i oralnih tkiva pacijenta). U ovom istraživanju dva OPG su načinjena pre početka restaurativne i protetičke terapije svakog pacijenta - prvi iz serije OPG, a drugi, zbog sumnje na sistemsku osteoporozu, pre početka lečenja osteoporoze, odnosno kod manjeg broja ispitanih pacijenata u pauzi u uzimanju medikamenata za sistemsku terapiju i lečenje osteoporoze čitavog skeleta.

Kada je reč o stanju vilica i koštanoj gustini u površinama kostiju vilica (posebno kosti donje vilice), najbolje bi bilo u svakodnevnoj praksi utvrditi smanjenja gustine kosti u stadijumu osteopenije. U pogledu utvrđivanja promena u sastavu i gustini kosti usled osteoporoze, OPG treba da postoji kao rendgen, odnosno pomoćni dijagnostički nalaz na početku osteoporoze (na 
prelazu osteopenije u osteoporozu), kada slojevi kostiju nisu u velikom stepenu razgrađeni, što se može desiti u uznapredovalim stadijumima ove bolesti. Nedostatak prikazivanja donjih vilica na OPG je taj što je, usled fiksiranja položaja glave i brade $u$ plastičnom kućištu ortopantomografskog aparata, prisutna blaga superpozicija držača - naslona za bradu prema površinama kosti ispod donjih sekutića. Zbog toga bi preporuka bila da se, radi procene smanjivanja gustine kosti ispod donjih sekutića (a to su regioni sa dosta spongiozne kosti, koja je upravo najviše podložna razgradnji usled osteoporoze), posebno načini RAG.

\section{ZAKLJUČAK}

Gustina kosti u gornjoj i donjoj vilici je uvek smanjena usled osteoporoze. Pre početka restaurativne terapije osobe obolele od osteoporoze treba načiniti RAG i OPG, označiti referentne linije, sagledati oblike i konture koštanih grebenova i proceniti gustinu kosti. 